\title{
Changes in Psychosocial Adjustment of Adolescent Girls in the Lessons of Physical Education
}

\author{
Šarūnas Klizass ${ }^{1}$, Romualdas Malinauskas ${ }^{1}$, Diana Karanauskiené \\ Žibuoklè Senikiené ${ }^{3}$, Irina Kliziené ${ }^{4}$ \\ ${ }^{1}$ Department of Health, Physical and Social Education, Lithuanian Sports University, \\ ${ }^{2}$ Language Centre, Lithuanian Sports University, \\ ${ }^{3}$ Department of Physiology, Medical Academy, Lithuanian University of Health Science, \\ ${ }^{4}$ Department of Physical Education, Kaunas University of Technology, Lithuania
}

Key Words: psychosocial adjustment; adolescent girls; lessons of physical education; educational experiment.

Summary. Objective. The aim of the present study was to establish the changes in psychosocial adjustment of adolescent girls in the modified lessons of physical education.

Material and Methods. An experimental design was used in the study. The experimental group included 14- to 15-year-old adolescent girls $(n=128)$, and the control group comprised adolescent girls of the same school and the same age $(n=137)$. The girls of the experimental group participated in modified physical education lessons. Once a month, they had a theory class where they received knowledge on communication disorders among adolescents and ways of preventing them by means of physical activities. In practical classes, the girls of the experimental group had sports games (basketball, volleyball, and football), enhancing physical abilities, and Pilates exercises. For the estimation of the level of adolescents' psychosocial adjustment and its components (self-esteem and domination), an adapted questionnaire developed by Rogers and Dymond was applied. An adapted questionnaire developed by Huebner was administered to measure students' satisfaction with life.

Results. The analysis of the data demonstrated that when comparing the psychosocial adjustment of the adolescent girls in the experimental group before and after the experiment, a significant differences in the score of the psychosocial adjustment scale was established (53.81 $\pm 8.34 \mathrm{vs.}$ 59.41 $\pm 7.66, P<0.05)$. After the experiment, high life satisfaction was reported by $42.19 \%$ of the girls $(P<0.05)$.

Conclusions. After the educational experiment, the index of the psychosocial adjustment scale in the experimental group improved statistically significantly.

\section{Introduction}

The debate regarding the ideal amount of physical education lessons that the state is ready to support is a major controversial issue in many countries (1). The issues of the subject of physical education have been extensively explored in the works of Lithuanian scholars (2, 3); nevertheless, major attention has been paid to the development of physical qualities rather than to the characteristics of psychosocial adjustment. As physical education involves possibilities of the fulfillment of personality needs, development of physical education may evolve into a means supporting the individuality by fostering social cooperation, undertaking personal responsibility, and developing cultural understanding as well as belief in human values (4). For this reason, we attempted at revealing the characteristics of physical education lessons as a means to strengthen psychosocial adjustment in our work.

Correspondence to I. Klizienè, Centre for Physical Education and Sports, Department of Physical Education, Kaunas University of Technology, K. Donelaičio 73, 44248 Kaunas, Lithuania E-mail: irina.kliziene@ktu.lt
Physical education is a forum for teaching youth effective motor skills, providing psychosocial adjustment, and producing knowledge on general health. School physical education experiences may play a critical role in increasing adolescent girls' physical activity levels by influencing physical activity behaviors at school (5), during leisure time, and later in life $(6,7)$. To develop interventions that are more effective, it is important to understand what activities interest adolescent girls and explore the factors associated with participation in physical activity. However, current programs of education reflecting the aspects of psychosocial adjustment, which could be applied during the lessons of physical education, are insufficient (8). Besides, it has not been proven by research yet that the lessons of physical education are the most accessible and favorable methods of strengthening students' psychosocial adjustment. In our research concerning the strengthening of psychosocial adjustment of adolescent girls during the lessons of physical education, more various and 
extensive methodologies were employed for the exploration of psychosocial adjustment so that they would most precisely contribute to the discovery of social and psychological peculiarities of students of this age group.

It has been established that physical activity has a significant impact on psychosocial adjustment of adolescents. Psychosocial adjustment during adolescence may be interpreted as an attempt of adolescents to discover their place, to alter in order to adapt, and to alter the place in order to adapt it to themselves. It is essential to explore the adolescence age during which the "flash" of motor needs takes place together with the active sexual maturation as well as rapid growth and development of all the organs and systems of the body. Adolescents who for some reasons find it hard to communicate with their peers feel isolated and separated from the environment, further lose confidence in their own powers, lose self-respect, and worsen their self-esteem due to regular failures (9). It has been suggested by Fergusson and Woodward (10) that one important explanation for the apparent continuity between early behavior problems and later negative life outcomes lies in the influence of psychosocial adjustment background factors that are associated with both adolescent behavior problems and later outcomes. We believe that the lack of psychosocial skills and the issues associated with psychosocial adjustment in adolescence usually result in the issues associated with mental health in further life, which validates the high topicality of the research of psychosocial adjustment of adolescent girls. The hardships of psychosocial adjustment are usually attempted to reveal by the levels of functioning in the areas of behavior, emotions, self-esteem, and interpersonal relations as well as in academic/professional environment (11).

A review by Sallis et al. (12) indicated that many studies examined psychosocial adjustment correlates of total (structured and unstructured) physical activity. Two correlates associated with physical activity include self-efficacy and enjoyment $(12,13)$. Because girls spend a considerable amount of time at school, the school social climate that supports girls being physically active may also influence physical activity in girls (14). However, most previous work evaluated overall physical activity, and not structured activity, which may have a different set of predictors. Total physical activity is a combination of structured (e.g., physical education classes and organized sports and activity lessons) and unstructured physical activity, and many physical activity interventions for this age group are structured in nature. Because of this, there is a value in understanding the correlates of structured physical activity.
The aim of the present study was to establish the changes in psychosocial adjustment of adolescent girls in the modified lessons of physical education.

The originality of the study is the first-time extensive exploration of the characteristics of the components influencing psychosocial adaptation during the lessons of physical education. Besides, an extensive research on psychosocial adjustment of students during intense physical activity was performed. In this research, the attitude toward the psychosocial adjustment of students expressed in scholarly sources was confirmed. The selected components of the construct of psychosocial adjustment (positive selfevaluation and domination) revealed the novelty of this research as in scholarly literature no research dealing with the impact of the lessons of physical education on the alteration of indices of psychosocial adjustment of students of this age group has been found.

\section{Material and Methods}

Study Population. After receiving the approval from the Ethics Committee of our University, the schoolgirls were selected for the experiment applying a 2-stage sampling strategy: first, the school was randomly selected from the list of Kaunas city secondary schools, and then all the schoolgirls from the eight and ninth grades were examined (every second grade was experimental). The experimental group (EG) included 14- to 15-year-old adolescent girls $(n=128)$, and the control group (CG) comprised adolescent girls of the same school and the same age $(\mathrm{n}=137)$.

Instruments. Two questionnaires - the questionnaire by Rogers and Dymond (15) and the multidimensional students' life satisfaction scale by Huebner (16) - were used. The questionnaire by Rogers and Dymond was chosen for the evaluation of psychosocial adjustment (15). It has been translated into Lithuanian and adapted for the Lithuanian population (17). The questionnaire by Rogers and Dymond consisted of 101 items, and psychosocial adjustment was rated on a 7 -point scale. The respondents had to choose 1 answer of the 7 possible variants: "This is definitely not about me," a score of 0 ; "This does not look like me," a score of 1 ; "I doubt that this could be applied to me," 2 ; "I do not dare to apply it to me," a score of 3; "This is similar to me, but I am not sure," a score of 4; "This is similar to me, " a score of 5; and "This is definitely about me," a score of 6 .

The main subscale that best reveals the nature of psychosocial adjustment is an adjustment subscale (internal validity of this subscale [Cronbach $\alpha$ ] was 0.76). The subscale includes 67 items of the questionnaire. Besides the psychosocial adjustment subscale, other subscales (self-esteem and dominance) 
were analyzed as well, which helped reveal person's psychosocial adjustment. The self-esteem subscale consisted of 18 items. Cronbach $\alpha$ of the self-esteem subscale was 0.72 for the present sample. The subscale "dominance" consisted of 9 items. Cronbach $\alpha$ of the subscale "dominance" was 0.72 for the present sample.

The multidimensional students' life satisfaction scale (16) is a 7-item self-report inventory. The subjects had to choose one answer to evaluate each statement as "strongly disagree," "disagree," "neither disagree nor agree," "agree," and "strongly agree." The items were rated on a 5-point Likert scale ranging from 1 (strongly disagree) to 5 (strongly agree). Two items (the third and the fourth) were adverse, and the results indicated lying. The level of life satisfaction was rated as very high (a score of 6.0), high (5.9-4.9), moderate (4.8-3.9), low (3.8-2.9), and very low (2.8-1). The internal consistency of the questionnaire was assessed by the Cronbach $\alpha$ coefficient. Cronbach $\alpha$ of this scale was 0.86 for the present sample.

Statistical Analysis. The data analysis was performed using the Statistical Package for Social Sciences (SPSS) version 13. The KolmogorovSmirnov test was applied for normality verification. It was established that the data of multidimensional students' life satisfaction scale were not normally distributed. The nonparametric chi-square test was used for the statistical analysis of these data. The distribution of the data of Rogers and Dymond's questionnaire was normal. Consequently, the $t$ test for independent samples was used to test the significance of the difference between the means of experimental and control groups. A significance level of 0.05 was chosen.

Procedure. The experiment was carried out in one Kaunas city secondary school from September 2010 to April 2011. Adolescent girls in the control group attended physical education lessons, which were not modified. The lessons took place 2 times a week (18). The girls in the experimental group participated in modified physical education lessons 2 times a week. Once a month, they had a theory class where they received knowledge on adolescents' communication disorders and ways of preventing them by means of physical activities. In practical classes, the girls in the experimental group had sports games (basketball, volleyball, and football) enhancing physical abilities (18) and Pilates exercises.

The adolescent girls in both the experimental and control groups filled in the questionnaires in the presence of a teacher and a researcher who looked after the course of the work and instructed the respondents. The survey lasted for 30-35 minutes. Physical education lessons for both groups (experimental and control) were conducted by the same teacher who was the author of the research. The study followed the principles of prior informed consent and voluntary participation, so the schoolgirls were explained the aim of the research, and those who refused to participate in the research could leave the study. The girls were also informed about the anonymity of the research.

The study was carried out in several stages. The girls in the experimental and control groups underwent the initial testing of their psychosocial adjustment, and later the girls in the experimental group experienced an experimental impact (the program of enhancing psychosocial adjustment in the lessons of physical education). After the experiment, all the subjects (265 adolescent girls) in the experimental and control groups were tested again.

\section{Results}

The results of the alteration of the levels of the psychosocial adjustment of the adolescent girls in the experimental and control groups were compared before and after the educational experiment. Before the educational experiment, there was no significant difference in the score of the psychosocial adjustment scale comparing both the groups (53.81 \pm 8.34 vs. $51.92 \pm 6.3, P>0.05)$. The analysis of the data demonstrated that when comparing the psychosocial adjustment of the adolescent girls in the experimental group before and after the experiment, a significant difference in the psychosocial adjustment score was observed comparing the results before and after the experiment $(53.81 \pm 8.34$ vs. $59.41 \pm 7.66 ; t=-2.03, P<0.05)$, although this cannot be said about the results of the psychosocial adjustment in the control group (Fig. 1).

Analysis of the self-esteem scale showed that the results of the experimental and control groups before the educational experiment were similar: there was no significant difference in the score comparing the experimental and control groups (57.43 \pm 12.80 vs. $55.90 \pm 10.41 ; t=1.06 ; P>0.05$ ) (Fig. 2 ).

The repeated research after the strengthening of the psychosocial adjustment of the adolescent girls during the lessons of physical education showed that the results of the experimental group after the educational experiment changed significantly in comparison with those before the educational experiment (a score of $60.52 \pm 11.98$ vs. $57.43 \pm 12.80$; $t=-1.99, P<0.05)$ (Fig. 2). Thus, a certain level of self-esteem is formed when reflecting on the results of one's activity and conceiving how one is assessed by others. An adequate self-esteem allows a critical insight into oneself and coherence of one's opportunities with tasks of various degrees of complexity.

The analyses performed at the beginning of the experiment showed that before the experiment, the 


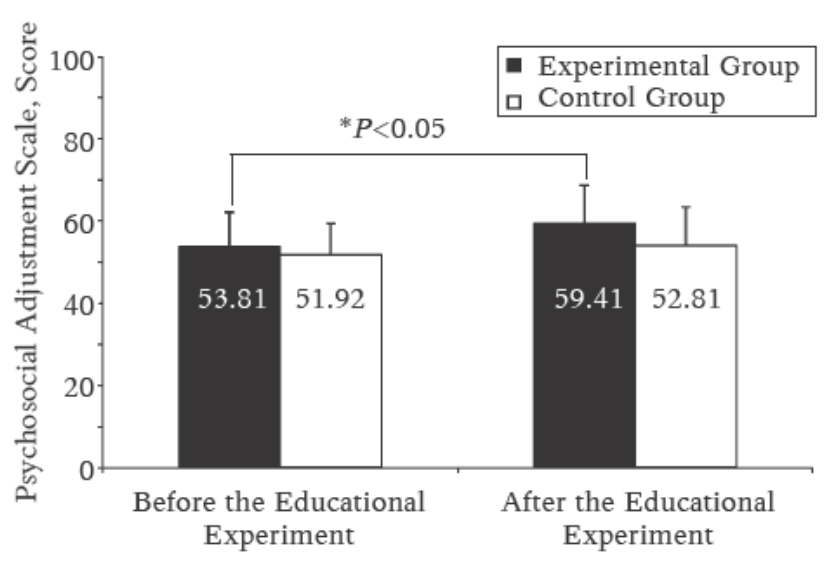

Fig. 1. The level of adolescents' psychosocial adjustment before and after the educational experiment

levels of domination of adolescent girls in the experimental group were slightly higher than those in the control group (44.04 \pm 13.13 and $42.42 \pm 11.22$, respectively). Nevertheless, the difference in terms of the levels of dominance between the groups before the experiment was not significant $(t=1.08$; $P>0.05)$. When exploring the alteration of dominance during the educational experiment, it became clear that after the program of strengthening psychosocial adjustment during the lessons of physical education the level of dominance of the members in the experimental group increased significantly (from a score of $44.04 \pm 13.13$ to $47.24 \pm 11.51$; $t=-2.07, P<0.05)$, although the same cannot be said about the results of the level of domination in the control group (a score of $42.42 \pm 11.22$ before the educational experiment and $40.91 \pm 10.94$ after the educational experiment) $(P>0.05)$ (Fig. 3).

Girls' life satisfaction the experimental and control groups was compared before the experiment and after it. It was established that the schoolgirls' life satisfaction tended to change. Before the experiment, the majority $(59.12 \%)$ of the schoolgirls in the control group were moderately satisfied with life. The girls in the experimental group (65.63\%) were also moderately satisfied with their life. The level of life satisfaction in both groups was similar $\left(\chi_{2}^{2}=1.47 ; P>0.05\right)$.

The repeated testing after the psychosocial adjustment program in physical education lessons showed that the educational impact on the girls in the experimental group was effective, i.e., their indices of high life satisfaction changed. After the experiment, high life satisfaction was reported by $42.19 \%$ of the girls $\left(\chi_{2}^{2}=6.67 ; P<0.05\right)$. The percentage of the adolescent girls in the experimental group reporting low life satisfaction decreased from $7.03 \%$ to $3.91 \%$. However, the difference of life satisfaction in the control group before the experiment and after it was not statistically significant

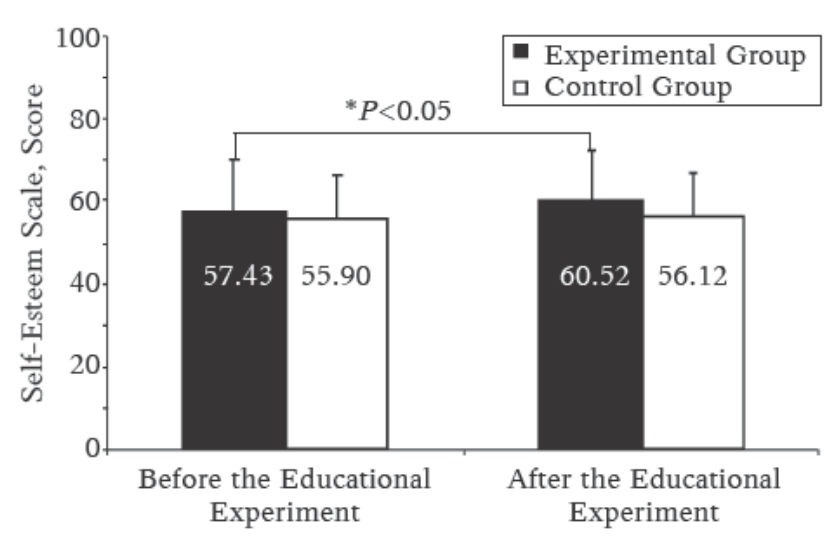

Fig. 2. The level of adolescents' self-esteem before and after the educational experiment

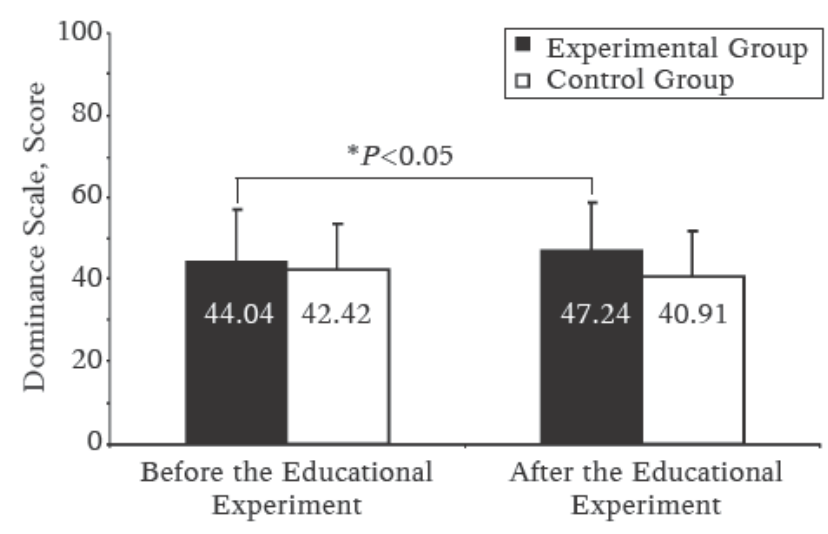

Fig. 3. The level of adolescents' dominance before and after the educational experiment

$(P>0.05)$ (Table). Thus, it can be suggested that after the program of enhancing psychosocial adjustment in physical education lessons, there were more adolescents who were seeking superiority, making more courageous decisions, and were more socially adaptive.

\section{Discussion}

The educational experiment was carried out in the pedagogical system of physical education. We applied a modified system of physical education lessons aiming at enhancing the psychosocial adjustment of the adolescent girls in the experimental group. While developing the program, we referred to the suggestions by other researchers (18) that educational programs should be developed on the basis of the needs of a certain social group depending on the problems the program was meant to solve. The program foresees the models of desired behaviors, their structure, and the aims and appropriate methods of physical education lessons. Aiming at enhancing the psychosocial adjustment of the schoolgirls in the experimental group, we focused on the fundamental personal needs of the adoles- 
Table. The Level of Adolescents' Life Satisfaction Before and After the Educational Experiment (\%)

\begin{tabular}{|c|c|c|c|c|c|c|}
\hline \multirow{2}{*}{$\begin{array}{l}\text { Level of Life } \\
\text { Satisfaction }\end{array}$} & \multicolumn{2}{|c|}{ Experimental Group } & \multirow[b]{2}{*}{$\chi^{2}$ and $P$} & \multicolumn{2}{|c|}{ Control Group } & \multirow[b]{2}{*}{$\chi^{2}$ and $P$} \\
\hline & $\begin{array}{c}\text { Before the } \\
\text { Experiment }\end{array}$ & $\begin{array}{c}\text { After the } \\
\text { Experiment }\end{array}$ & & $\begin{array}{c}\text { Before the } \\
\text { Experiment }\end{array}$ & $\begin{array}{c}\text { After the } \\
\text { Experiment }\end{array}$ & \\
\hline $\begin{array}{l}\text { Low } \\
\text { Moderate } \\
\text { High }\end{array}$ & $\begin{array}{c}7.03 \\
65.63 \\
27.34\end{array}$ & $\begin{array}{c}3.91 \\
53.91 \\
42.19\end{array}$ & $\begin{array}{c}\chi_{2}^{2}=6.67 \\
P<0.05\end{array}$ & $\begin{array}{l}10.22 \\
59.12 \\
30.66\end{array}$ & $\begin{array}{c}8.76 \\
49.64 \\
41.61\end{array}$ & $\begin{array}{c}\chi_{2}^{2}=3.56 ; \\
P>0.05\end{array}$ \\
\hline
\end{tabular}

cents in this age group: self-confidence $\leftrightarrow$ self-esteem $\leftrightarrow$ life satisfaction.

These needs are satisfied in self-esteem activities, demands for communication, and vigorous physical activity. The purpose of this study was to establish the changes in psychosocial adjustment of adolescent girls attending the modified lessons of physical education. It was established that the psychosocial adjustment of the adolescent girls in the experimental group and the components of this construct (self-esteem, dominance, and indices of satisfaction with life) after the enhancement of psychosocial adjustment in the lessons of physical education were higher in comparison with those of the experimental group before the educational experiment and those of the control group before and after the experiment. Psychosocial adjustment in adolescence can be explained as adolescents' attempts to search for their own place, change themselves in order to adjust in that place, and change the place in order to adjust it to themselves. Thus, this age period is of great interest and requires in-depth research.

It has been established that physical activity has a significant impact on the psychosocial adjustment of middle school-aged students. Due to multiple reasons, the lessons of physical education are an excellent opportunity to get children interested in intense physical activities (19).

Research (20) shows that during physical education lessons students strive for improvement and satisfaction in vigorous physical activity; thus, physical education acquires a pedagogical meaning and value. As physical education is linked to many personal qualities as morality, self-confidence, selfactualization, and self-esteem, it helps enhance psychosocial adjustment for schoolchildren (21). Ussher et al. (22) found that low levels of self-reported physical activity were independently associated with diminished psychological well-being among adolescence. Barr-Anderson et al. (23) established that interventions to increase self-efficacy and making physical education classes more enjoyable for girls might result in greater participation in structured physical activity and higher overall physical activity levels among adolescent girls. Scientists estimated that cheerleading/dance, dance, and swimming were traditionally popular physical activities among young females (23). Our research results indicated that the modified lessons of physical education, i.e., application of sports games (basketball, volleyball, and football) and Pilates exercises, increased the indices of adolescent girls' psychosocial adjustment, self-esteem, dominance, and satisfaction with life. Thus, after the evaluation of adolescent personality traits, the characteristics of psychological-educational enhancement of psychosocial adjustment of the girls in the experimental group in the lessons of physical education, we included modern Pilates exercises and methods, which strengthen abdominal muscles, back muscles, and the whole body as well as help muscles burn redundant fats and increase muscles tonus and length (24). Within the last 2 decades, Pilates exercises have infused new insights into the fitness industry and lower back rehabilitation methods. Current Pilates exercise styles can be divided into a repertory approach and a modern approach (24). The repertory approach, being the traditional method, uses set exercise sequences and set numbers of repetitions with little modification for individual problems. However, in the modern approach, the initial emphasis is on understanding the body and improving awareness by tailoring the exercises to particular needs, weaknesses, and strengths of adolescent girls. In this respect, modern Pilates trainees should think of their bodies as single integrated units with the goal of establishing a stable central core, around which all movements take place (25). Pilates exercises lasted for 10 to 20 minutes during the 2 weekly lessons of physical education in the experimental group for the whole school year. All those characteristics helped adolescents enhance the main components of psychosocial adjustment in physical activities during the physical education lessons, which increased the overall level of adolescent girls' psychosocial adjustment.

We assume that sports activities in physical education lessons create close interrelations with peers, which prevents adolescents from being lonely. Experience of loneliness and other emotionally hard events are linked with increased discomfort, which hinders smooth psychosocial adjustment to the environment. If the environment in the lessons of physical education is oriented toward communication and cooperation, and the preconditions for interaction with social environment are substantial, the adolescent girls can meet their most important 
needs, and they have confidence in themselves and follow the provisions of justice. Moreover, the effects of the perceived school climate and psychosocial or behavioral adjustment are often unidirectional rather than bidirectional, underscoring the role of the perceived school climate in the psychosocial and behavioral health of adolescents (26). However, Knowles et al. (27) established that physical activity levels declined considerably over 12 months in early adolescent girls, which in itself warrants considerable attention, and although this variance in physical activity was partly accounted for by physical selfperceptions and psychosocial adjustment, this was a relatively small contribution, and other factors associated with this drop in physical activity have to be taken in consideration. This drop in physical activity in adolescent girls is coincident with maturation, which usually occurs around the age of $12-13$ years; yet, few studies have examined the direct influence of maturation on physical activity. However, from their own research findings, Crocker et al. (28) suggested that a focus on early adolescent girls may be more appropriate in understanding physical activity behavior because physical self-perceptions became relatively stable during mid to late adolescence. Research examining physical self-perceptions during early adolescence is somewhat sparse, and during this time, there is also a documented maturity-related decrease in physical activity in adolescent girls (28). Summarizing the results of the educational experiment on psychosocial adjustment and its components (self-esteem and domination), we can state that even after a short period of the impact there are certain tendencies, i.e., improved psychosocial adjustment helps overcome various critical situations. This proves the importance of adolescents' girls mutual relations as the main component of psychosocial adjustment.

The analysis of our research results showed that the educational impact in the experimental group affected the adolescents, and their life satisfaction indices increased. The adolescent girls evaluated their life satisfaction as high. However, Malinauskas et al. (29) applied the measures of psychological impact to assess the influence of autogenic training on mental health, life satisfaction, self-control, and the

\section{References}

1. Puehse U, Gerber M. International Comparison of Physical Education. Concepts, problems, prospects. Aachen: Meyer and Meyer; 2005.

2. Blauzdys V, Vilkas A. Kūno kultūros žinių poveikis gimnazijos mokinių fiziniam parengtumui. (Influence of physical training knowledge on physical fitness of gymnasium students.) Ugdymas. Kūno kultūra. Sportas (Kaunas) 2007;1:10-5.

3. Jankauskienė R. Lietuvos gyventojų fizinio aktyvumo skatinimo strategija: kūno kultūra ar kūno kultas? (Lithuanian level of stress. The educational experiment aimed at creating conditions to enhance adolescents' mental health. The researchers found that before the educational experiment, the life satisfaction indices of the schoolchildren engaged in sports in the control group were moderate. Although after the experiment more subjects in the control group reported greater satisfaction with life, the difference in the indices before and after the experiment were not statistically significant (29). Educators, psychologists, and parents have long been solving the dilemma how to make children happy. This issue describes the state, which appears under certain conditions in life (18). Keyes (30) performed a study where he interviewed 3000 senior schoolchildren aiming at determining the relation between mental health, feeling of well-being, and life satisfaction. The author found that $28 \%$ of the respondents had symptoms of depression; $72 \%$ of the schoolchildren demonstrated good feelings of well-being, and their mental health statistically significantly correlated with their life satisfaction. After performing a questionnaire survey, Diener and Seligman (31) divided adolescents into two groups: "very happy" and "unhappy." They found that "very happy" schoolchildren did their work very well, and their learning outcomes were much better in comparison with those of their "unhappy" counterparts. Adolescents who are "unhappy" at school and at home very often feel lonely (31). Trainor et al. (32) found that individuals low in self-esteem and life satisfaction tend to participate in activities that are unstructured and unchallenging. Our research results showed that adolescent girls evaluated their life satisfaction better after the educational experiment than before it.

\section{Conclusions}

After the educational experiment, the index of the psychosocial adjustment in the experimental group improved statistically significantly as well as the values of the 3 structural components of the psychosocial adjustment: self-esteem, dominance, and life satisfaction.

\section{Statement of Conflicts of Interest}

The authors state no conflict of interest.

physical activity strategy: the culture of the body or the body cult?) Medicina (Kaunas) 2008;44(5):346-55.

4. Kardelienè L, Kardelis K. Pedagoginè komunikacija kūno kultūros veikloje. (Pedagogic communication in the activities of physical education.) Kaunas: LKKA; 2006.

5. Vasalampi K, Salmela-Aro K, Nurmi JE. Education-related goal appraisals and self-esteem during the transition to secondary education: a longitudinal study. Int J Behav Dev 2010;34:481-90.

6. Grunbaum J, Kann L, Kinchen S, Ross J, Hawkins J, Lowry R. Youth risk behavior surveillance - United States, 2003. 
MMWR Surveil Summ 2004:53:1-96.

7. Donnelly JE, Greene JL, Gibson CA, Smith BK, Washburn RA, Sullivan DK, et al. Physical Activity Across the Curriculum (PAAC): a randomized controlled trial to promote physical activity and diminish overweight and obesity in elementary school children. Adv Prev Med 2009;49:336-41.

8. Baker BL, Birch LL, Trost SG, Davison KK. Advanced pubertal status at age 11 and lower physical activity in adolescent girls. J Pediatr 2007;151:488-93.

9. Ellickson PL, McGuigan KA. Early predictors of adolescent violence. Am J Public Health 2000;90:566-77.

10. Fergusson DM, Woodward LJ. Educational, psychosocial and sexual outcomes of girls with conduct problems in early adolescence. J Child Psychol Psychiatry 2000;41:779-92.

11. Bishop M. Quality of life and psychosocial adaptation to chronic illness and acquired disability: a conceptual and theoretical synthesis. J Rehabil 2005;7:215-21.

12. Sallis JF, Prochaska JJ, Taylor WC. A review of correlates of physical activity of children and adolescents. Med Sci Sports Exerc 2000;32:963-75.

13. Dishman RK, Motl RW, Saunders R, Felton G, Ward DS, Dowda M, et al. Enjoyment mediates effects of a schoolbased physical-activity intervention. Med Sci Sports Exerc 2005;37:478-87.

14. Birnbaum AS, Evenson KR, Motl RW, Dishman RK, Voorhees CC, Sallis JF, et al. Scale development for perceived school climate for girls' physical activity. Am J Health Behav 2005;29:250-57.

15. Rogers CR, Dymond R. Psychotherapy and personality change. Chicago: University of Chicago Press; 1954.

16. Suldo SH, Huebner ES. Is extremely high life satisfaction during adolescence advantageous? Soc Indic Res 2006;78: 179-203.

17. Klizas Š. Viduriniojo mokyklinio amžiaus moksleivių psichosocialiné adaptacija ir jos stiprinimas per kūno kultūros pamokas. (Psychosocial adjustment for students of middle school age and its strengthening during lessons of physical education.) [dissertation]. Kaunas: LKKA; 2009.

18. Lithuanian general education programs. Physical education. Vilnius: Education Supply Centre (in Lithuanian); 2009.

19. Malinauskas R, Klizas S, Šniras Š. Viduriniojo mokyklinio amžiaus moksleivių socialinė adaptacija kūno kultūros pamoku metu. (Social adjustment among students of middle school age during physical education lessons.) Ugdymas. Kūno kultūra. Sportas (Kaunas) 2008;2(69):52-6.

20. Bobrova L. Būsimųių kūno kultūros pedagogų psichoso- cialinès adaptacijos ypatumai gyvenimo stiliaus kaitos kontekste. (Peculiarities of psycho-social adjustment of future physical education pedagogues in the context of life-style changes.) Jaunųjų mokslininkų darbai (Šiauliai) 2009;1(22): 24-32.

21. Palujanskienė A. Savęs vertinimo ir savijautos sąsajos ugdymo procese. (Link physical education for self-actualization and self-esteem.) Ugdymas. Kūno kultūra. Sportas (Kaunas) 2003;4:41-5.

22. Ussher H, Owen CG, Cook DG, Whincup PH. The relationship between physical activity, sedentary behavior and psychological wellbeing among adolescents. Soc Psychiatry Psychiatr Epidemiol 2007;42:851-56.

23. Barr-Anderson DJ, Young DR, Sallis JF, Neumark-Sztainer DR, Gittelsohn J, Webber L, et al. Structured physical activity and psychosocial correlates in middle-school girls. Prev Med 2007;44:404-9.

24. Isacowitz R. Pilates. Champaign: Human Kinetics; 2006.

25. Latey P. The Pilates method: history and philosophy. J Bodyw Mov Ther 2001;5(4):275-82.

26. Way N, Reddy R, Rhodes J. Students perceptions of school climate during the middle school years: associations with trajectories of psychological and behaviour adjustment. Am J Community Psychol 2007;40:194-213.

27. Knowles AM, Niven AG, Fawkner SG, Henretty JM. A longitudinal examination of the influence of maturation on physical self-perceptions and the relationship with physical activity in early adolescent girls. J Adolesc 2009;32:555-66.

28. Crocker P, Sabiston C, Kowalski K, McDonough M, Kowalski N. Longitudinal assessment of the relationship between physical self-concept and health-related behavior and emotion in adolescent girls. J Appl Sport Psychol 2006; 18:185-200.

29. Malinauskas R, Malinauskienė V, Dumčienè A, Dumbliauskas A, Šeščilienè IM, Šniras Š. Sportuojančių moksleivių psichikos sveikatos ugdymo, taikant psichologinio poveikio priemones, ypatumai. (Peculiarities of sporting schoolchildren mental health training, using psychological intervention.) Visuomenès sveikata (Vilnius) 2007;1:40-5.

30. Keyes CLM. The mental health continuum: from languishing to flourishing in life. J Health Soc Behav 2002;43:207-22.

31. Diener E, Seligman ME. Very happy people. Psychol Sci 2002;31:81-4.

32. Trainor S, Delfabbro P, Anderson S, Winefield A. Leisure activities and adolescent psychological well-being. J Adolesc 2010;33:173-86. 